\title{
HORSE-BREEDING OF THE OASIS OF SURKHAN
}

\author{
(CKabulov E., Sc.D., Termez State University, Termez, \\ Uzbekistan,eshbolta@mail.ru \\ CRajapova S., Termez State University, Termez, Uzbekistan,

\section{КОНЕВОДСТВО СУРХАНСКОГО ОАЗИСА}

\author{
(СКабулов Э. A., Sc.D., Термезский государственный университет, \\ 2. Термез, Узбекистан, eshbolta@mail.ru \\ СРажабова С. Б., Термезский государственный университет, г. Термез, Узбекистан
}

Abstract. Since ancient times in Uzbekistan, special attention has been paid to horse breeding. We can see this in dastans and traditions, where poets and bakhshis sang about mythical horses. And most importantly, the horse was very much appreciated as a companion of a horse. As in other regions of the republic, special attention was paid to the development of horse breeding in the Surkhan oasis. Several breeds of horses were bred in the oasis, they were called 'adobe', 'jiyran', 'turik', 'buz' and others by color. Uzbeks mainly bred 'Karabair', 'Lakay', 'Turkman', and sometimes Arab ones. For breeding local breeds of horses 'Karabair' were used breeds of Turkmen, Arab and Mongolian horses. By breeding horses such breeds of 'Karabair' horses as 'Uzbek', 'Miyenkul', 'Urgut' and others were bred. Also, horses were named for their age. A newborn horse was called a 'kulun', up to one year a foal, from a year and a half to two years a strigunok, a twothree year old foal, a third year a gunan, a three-four year old dunan, a male after four years a stallion, a female mare. In the Surkhan oasis, Turkmen horses were widely used as a vehicle, they participated in horse racing, racing and kupkari (equestrian competition in which the participants of the competition rip out goat carcass from each other). Responsible for the conservation and reproduction of horse breeds were men. They promptly gave horses food, took them for a walk. The horses that took part in the races, kupkari were raised according to special methods and customs. Such horses were fed from spring to late autumn, with the arrival of autumn they were walked and prepared for competitions. Horses were considered not only a vehicle; they were the most expensive and valuable commodity. At that time, the best horses were estimated from 400 to 600 rubles, and Turkmen horses to 1000 rubles. In a word, horses were not only expensive goods; they were considered the best friend and helper of a horseman.

Аннотащия. С давних времен в Узбекистане особое внимание уделялось коневодству. Это мы можем видеть в дастанах и преданиях, где поэты и бахши воспевали о мифических лошадях. А самое главное, конь очень ценился как спутник джигита. Как и в других регионах Узбекистана, развитию коневодства в Сурханском оазисе уделялось особое внимание. В оазисе разводили несколько пород лошадей, по окрасу их называли саман, жейран, турик, буз и др. Узбеки в основном разводили карабаирских, локайских, туркманских лошадей, иногда разводили и арабских. Для разведения местной карабаирской породы лошадей были использованы породы туркменских, арабских и монгольских лошадей. Путем скрещивания с участием карабаирских лошадей были выведены такие породы как узбекская, миёнкулская, ургутская и др. Также, лошадей называли по их возрасту. Новорожденная лошадь называлась «кулун», до одного года - жеребенок, от полтора до двух лет - стригунок, двух-трехлетний жеребенок, по третьему году — гунан, трех-четырехлетний - дунан, самца после четырех 
лет - жеребцом, самку — кобылой. В Сурханском оазисе туркменские лошади широко были использованы как транспортное средство, они участвовали в скачках, бегах и купкари (конно-спортивное состязание, на котором участники состязания вырывают друг у друга козлиную тушу). Ответственными за сохранение и размножение пород лошадей были мужчины. Они своевременно давали лошадям корм, выводили на прогулку. Лошади, которые принимали участие на скачках, купкари воспитывались по особым методам и обычаям. Таких лошадей откармливали с весны до поздней осени, с приходом осени их выгуливали и готовили к состязаниям. Лошади считались не только транспортным средством они были самым дорогим и ценным товаром. По тем временам самые лучшие кони оценивались от 400 до 600 рублей, а туркменские лошади до 1000 рублей. Одним словом лошади были не только дорогим товаром они считались лучшим другом и помощником джигита.

Keywords: Karabayir, Lakay, Turkmen, Arabic, Saman, Jiyran, Turik, Buz, Temir kuk, Akyal, Chagir, kulun, tay, taychak, gunan, dunan, baital, kupkari, running, horse racing.

Ключевые слова: карабаирская, лакайская, туркменская, арабская, саман, жейран, турик, буз, темир кук, окел, чагир, кулун, тойчок, той, гунан, дунан, байтал, купкари, бега, скачки.

Long before the development of horse-breeding was cared in Uzbekistan. Poems and folk-lore songs were sung about Legendary Horses. Horses were valued as the company of guys, for this reason such kind of narration was spread among people: "If you have only one day to live, buy a horse, and if you have two days, buy a wife" [8, p. 78]. There are lots of different horses in our homeland: Karabayir, Lakay, Turkmen, and a few Arabic horses, the most of all are Karabayirs. Karabayir horses were mainly spread over the basion of Zarafshan, the valley of Fergana and the valley of Tashkent [16, p. 191]. Horese-breeding played major role in the national economy of the people of Surkhan valley. There were a lot of kinds of horses that were named by their colours: saman, jiyrfn, turik, buz, kuk, temirkuk, akyal, chagir and so on [5, p. 46]. Firstly, horses were used as a transport of a facility of large lifestock, and secondly as a working animal. And continuously aggression moves also caused to development of horse-breeding [10, p. 48]. Horses were also important as a transport. In Emirate there were 400 thousand riding horses [15, p. 11], from these 100 thousand were breed of hisor, 50 thousand were Turkmen horses, 230 thousand were Kyrgyz horses and 20 thousand were Bukhara horses. Uzbeks mainly multiplied Karabayir, Lakay, Turkmen, and less Arabic horses [11, p. 286]. Turkman, arab and mugyul horses were used to create local breeds of Karabayir horses [7, p. 263]. Uzbek, miyonkul and urgut horses were multiplied by breeding Karabayir horses. The strongest horses were the horses which breeded by Karabayir and kazak horses, and they were used in loading in all cities of Central Asia [17, p. 227]. Lakay horses were raised in the south of Uzbekistan and Tajikistan. These horses were characterized by beautiful appearance, and they could walk $80 \mathrm{~km}$ a day carrying 150-160 kg loads in mountain roads [8, p. 79]. Arabic horses were mainly spread over the pond of Zarafshan, the valley of Bukhara and the territory of Karshi. This horse is distinguished from other horses with walking long distance without water and fodder. Turkmen horses were multiplied by Nurataturkmans who lived in the bottom of Zarafshan, Khorezm and in the south-western part of Surkhandarya. This horse was mainly used as a facility of transport, kupkari and horse-race [16, p. 192]. There were 145 thousand horses in the valley of Surkhan [12, p. 65], and they were used in freshing flour, in embroiling lubricant, in loading cargos and in kupkari [16, p. 190]. And horse-herders were named and characterized according to their ages. For example, newborn was kulun, one-year old horse is taychak, up yo 1.5- 
2 years old is toy, 2-3 years old is gunan, 3-4 years old is dunan, after 4 years old males are called aygir, females are called baytal. From the 5 years aygirs were joined to 'kupkari-ulok' [5, p. 46].

Horses were also differentiated according to their colours and their parts of a body. The teeth of beautiful and healthy horse were white and rightly connected. Their low lips were long, foreheads were wide, temples were open, ears were long and openly, necks were right and fat, hard and long, tale was sensitive wool and short, eyelashes were black, shortly back and the low part of tail is wide, backs are full of flesh and stick together [6, p. 81]. If every horse has such things, these horses are very valuable. Such kind of horses walks vigilantly on roads. They are always careful for riders and faithful for their owners. The best color of the horses is brown. Saman horse whose color is dark yellow, are also good horse. If saman horse has black points on its face, fleshy forehead and fleshy thigh, black eyes and lips, they are called nice horses. Blue horses are stubborn. But if blue horse has white hoofs, they are obedient [8, p. 80]. People paid great attention to bringing-up horses in the valley. Horses were looked after by young guys.

Horses were kept in stables. Special cribs were built for feeding horses. There was need for cribs, because horses ate hay in sprinkle way. One border of the crib was a wall of stable. The depth of the crib was 0.5-0.6 meters, and height was 1 meter [4. 2003]. In different areas wood was used as a crib. Horses were kept in a long distance from cattles, because breathing of cattles had badly influenced to horses. There was great attention for horse-feeding. Wheat juice were givenhorses every spring for making them strong and healthy. Main food of horses were lucerne, cut straw, barley. Ardob food was given for kupkari horses. Ardob was prepared by boiling water with wheat or barley flour. This food was stuffy especially before long journey of horses. In addition, food was carried in saddle bags during long walks. In public places horses were fed by hanging on their necks sacks with barley or other foods. Various foods were given to horses according to terms. Barley, dry lucerne and wheat cut straw were given especially in winter. Green lucerne was given in spring. And horses grazed in open fields too in spring months. Horses were watered 2-3 times a day in winter, and 4 times in summer [3. 2002].

There were special rules even in watering. The horse which was coming from a long way or took part in kupkari wasn't watered at once because this could cause horse's hoof catch cold. And horses weren't fed either in this time, because horse's digestion system worked slowly after sweating from long journey. The horse that running for goatling was fed in a detached ration. They were given wheat cutting straw adding barley in the morning and evening. And 4 types of dried barley was given too. At the feeding period, the horse was given $4 \mathrm{~kg}$ barley a day and it multiplied till 25-30 kg in a gradually way [8, p. 80-96]. Then the horses which fed 3-4 months were riden in the evenings and were made cold. Cooling period wasn't less 2 months, after that they were joined kupkari or goatling. Raw horses that looking after weren't joined kupkari without cooling. If they added, these horses became crippled. The most useful food was Lucerne among others, yug 'ichqa and wheat stalks were given in mountainous places. Horses which running for goatlingare looked after from spring to autumn, from the beginning of autumn they are got cold. Horses were also put to fields so that they graze freely. In autumn horses were brought to the field in which harvest was gathered, and horses were bound by long rope and their front hoofs were tangled so that they weren't stolen [2, p. 212]. As grooms say the rope of horse mustn't be less more 9 kuloch (measure).

Pregnant and nursian horses were fed on separately. It is admitted in historical sources that officials from the highest duties to the lowest generation paid great attention to bringing up thoroughbred horses. There were 200 pedigreed horses in the stables of Nasrullo who was Emir of Bukhara in 1826-1850, and nearly 300 horses in Allayor Farg'onachi's stable in 1870-1880 years [1, 9]. 
Wealth and average people also took breed from horses. Pregnant horses were fed on normally in order to develop their pregnancy. But people gave more food to kulun horses.

Horses that kept in stables were fed on ration and routine. Skin, hoofs, tail and hair of horses were taken care of attentively and stables were also kept clean. Spare parts of horses' hoofs were cut. Horses were swum in the rivers or streams in summer months.

Pregnant horses were kept on wheat cutting straw when 10 days left to their birth giving day. The time of birth was defined by the time of latest day the horse escaped. Pregnancy period lasted 11 months. Newborn horse was given only milk. If newborn horses were fed on well there was no need for additional food for 2-3 months. When baby horses are 6 months, they were separated from their mothers, and accustomed to rope. Training baby horses was started just after their birth. Besides it, young horses' skin and hoofs were taken care of constantly.

It is known that people determine exact age of the horse by watching their teeth. Front teeth of horses called shovel teeth and they were 12. Jaw teeth were 24. They settled up and down 6 teeth from 2 sides. Only aygirs have stake teeth, and biyas rarely have them. Stake teeth were settled on both sides of upper jaws and lower jaws, and also were in the middle jaws. Stake teeth grow when the horse is 4 years old. Ayg'irs have 40 teeth, and biyas have 36 teeth. Ages of horses determined by their shovel teeth. Constant teeth are bigger than milky teeth. The hole in the growing side of tooth called little bowl. Firstly age of horse is defined by looking constant teeth after milky teeth, then according to growing little bowls. Embezzler teeth grow 2 weeks after born. Middle shovel teeth appear during $1^{\text {st }}$ month, edge shovel teeth grow after 5-6 months. Little bowls of embezzler teeth spread at 1.5 years old, edge shovel teeth appear when the horse is 2 years old [18, p. 278].

When young horse is 2.5 years old upper and lower teeth spilled, and constant embezzler teeth grew. And at the age of 3.5, middle shovel teeth poured and constant teeth grew. And when horse is 4.5 years old edge shovel teeth spilled before growing constant teeth. If horses were fed on well, their teeth changed quickly.

After spilling milky teeth, and growing constant teeth, their ages are determined by watching eroding little bowls. 2 little bowls of teeth was eroded every year. Firstly, lower shovel bowls were eroded, and then the upper ones. In this process, the hole of bowl is eroded and track is left only, and getting smaller during the horse getting older. After 11 years old it is difficult to determine horse's age by watching its teeth. Horse is valued as a partner of a guy in the valley of Surkhan. The best horses are cost more than 400 roubles. The horse of Jurabek (previous nobleman of Shakhrisabz) was costed more than 600 rubles [13, p. 177]. Generally speaking, good horses weren't taken to bazaars. Normal horses were cost 35-47 roubles [9, p. 27]. At the same time people of Khorezm oasis sold their horses 20-40 roubles and they sold qorabayir horses 55-70 roubles. G. Bunvalot wrote in his collections that there were many strong and huge horses in Denaubeklik. People pay great attention to cattles, especially strong and beautiful horses. And for saving horses in normal position people put special round obstacles in front of their hoofs [2, p. 211].

In conclusion, horse is estimated as a guy's companion and genuses are taken care of.

\section{References:}

1. Arandarenko, G. (1881). Horse breeding. Turkestan Vedomasti, (9).

2. Bonvalot, G. (1889). Through the heart of Asia. Over the Pomir to India, II. London,

3. The author's field records according to the villages of Baisun (2002).

4. The author's field records according to the villages of Sherabad (2003).

5. Kabulov, E. (2002). What do you know about a horse. Mulakat (Communication), (3). 46.

6. Kaykavus. Kabusnama. (1994). Tashkent. 
7. Kalinin, V. I., \& Jakovlev, R. J. (1956). Horse breeding. Moscow.

8. Karmisheva, B. X. (1954). Uzbek lakays in the South of Tadjikistan. Stalinabad, 169.

9. Kap. Gintillo. (1886). The informations of the quarter master which belongs to the parts of Bukhara. complitation. geographic. topographic. Materials on Asia.Vip.XXI. St. Petersburg.

10. Logofet, D. N. (1909). Lawlessness countries. St. Petersburg.

11. The system of the nomadic and local inhabitands in the Department of Amudarya, Sirdarya region and informations according to the teaching of using land. (1915). I. II. Tashkent.

12. Pokotilo. The report according to the Central and Eastern areas of Bukhara.

13. Turkestanian collection, (118), 177.

14. The farm of Karakalpak In XIX - the beginning of XX centuries (thei nformations about historical-ethnographic atlas of Central Asia and Kazakhistan).

15. CSARUz, f. R-47, List.1, w.115 a, sheet 11.

16. Shaniazov, K. (1975). The main livestock industries in pre revolutionary Uzbekistan. (The communicatins of the farmic-cultural of the people of Central Asia and Kazakhistan). Moscow.

17. Shishov, A. (1904). Sarts. Ch. 1. Ethnography. the collection of the statistic materials according to Sirdarya region. Numb. XI. Tashkent,

18. Schekin, V. A. (1961). Livestock. Tashkent,

\section{Список литературь:}

1. Арандаренко Г. Коневодство // Туркестанские ведомости, 1881.№ 9.

2. Bonvalot G. Through the heart of Asia. Over the Pomir to India, Vol.II. London, 1889.

3. Полевые записи автора по селениям Байсуна, 2002.

4. Полевые записи автора по селениям Шерабада, 2003.

5. Кабулов Э.От хақида нима биламиз. // Мулоқат. 2002. № 3. Б. 46.

6. Кайковус. Кобуснома. Ташкент, 1994. 205 с.

7. Калинин В. И., Яковлев Р. Я. Коневодство. М. 1956.

8. Кармышева Б.Х. Узбеки-локайцы Южного Таджикистана. Сталинабад, 1954. 169 с.

9. Кап. Гинтылло. Сведения по интендантская части, собранные в Бухары // Сбор. геогр.,топогр. Материалов по Азии. Вып. ХХІ. СПб., 1886. С. 1-53.

10. Логофет Д. Н. Страна бесправия. СПб., 1909. 239 с.

11. Материалы по обследованию кочевого и оседлого туземного хозяйства и землепользования в Амударьинском отделе Сырдариньской области. Вып. I. II. Ташкент, 1915.

12. Покотило. Отчет о поездке в пределы центральной и восточной Бухары в 1886 г. Ташкент, 1888. 168 с.

13. Туркестанский сборник. Т.118. С. 177.

14. Хозяйство Каракалпакии в XIX - начале XX века (Материалы к историкоэтнографическому атласу Средней Азии и Казахстана).

15. ЦГА. РУз. Ф.Р-47, оп.1, д. 115 а, л.11.

16. Шаниязов К. Основные отрасли животноводства в до революционном Узбекистане (Хозяйственно-культурное традиции народов Средней Азии и Казахстана. Москва: Наука, 1975. C. 188-193. 
17. Шишов А. Сарты. Ч. 1. Этнография: сборник материалов для статистика Сырдариньской области. Вып. ХІ. Ташкент, 1904.

18. Шчекин В. А. Чорвачилик. Тошкент, 1961. 231 с.

Работа поступила

в редакциюю 11.10.2019 2.
Принята к публикациии 16.08.2019 2.

Ссылка для циитирования:

Kabulov E., Rajapova S. Horse-breeding of the Oasis of Surkhan // Бюллетень науки и практики. 2019. Т. 5. №11. С. 404-409. https://doi.org/10.33619/2414-2948/48/50

Cite as (APA):

Kabulov, E. \& Rajapova, S. (2019). Horse-breeding of the Oasis of Surkhan. Bulletin of Science and Practice, 5(11), 404-409. https://doi.org/10.33619/2414-2948/48/50 (in Russian). 